\title{
Cancer Activation and Polymorphisms of Human Cytochrome P450 1B1
}

\author{
Young-Jin Chun ${ }^{1}$ and Donghak Kim ${ }^{2}$ \\ ${ }^{1}$ College of Pharmacy, Chung-Ang University, Seoul, Korea \\ ${ }^{2}$ Department of Biological Sciences, Konkuk University, Seoul, Korea
}

(Received January 25, 2016; Revised February 29, 2016; Accepted March 1, 2016)

\begin{abstract}
Human cytochrome P450 enzymes (P450s, CYPs) are major oxidative catalysts that metabolize various xenobiotic and endogenous compounds. Many carcinogens induce cancer only after metabolic activation and P450 enzymes play an important role in this phenomenon. P450 1B1 mediates bioactivation of many procarcinogenic chemicals and carcinogenic estrogen. It catalyzes the oxidation reaction of polycyclic aromatic carbons, heterocyclic and aromatic amines, and the 4-hydroxylation reaction of 17 $\beta$-estradiol. Enhanced expression of P450 1B1 promotes cancer cell proliferation and metastasis. There are at least 25 polymorphic variants of $\mathrm{P} 4501 \mathrm{~B} 1$ and some of these have been reported to be associated with eye diseases. In addition, P450 1B1 polymorphisms can greatly affect the metabolic activation of many procarcinogenic compounds. It is necessary to understand the relationship between metabolic activation of such substances and P450 1B1 polymorphisms in order to develop rational strategies for the prevention of its toxic effect on human health.
\end{abstract}

Key words: Cytochrome P450 1B1, Cancer activation, Polymorphism

\section{INTRODUCTION}

Cytochrome P450 enzymes (P450s, CYPs) are heme-thiolate monooxygense enzymes found in a variety of living organisms including animals, fungi, bacteria, and plants (1). These are the major catalysts of oxidative metabolism of xenobiotic chemicals, and therefore have been a subject of numerous toxicological, pharmacological, and drug metabolism studies $(2,3)$.

In 1958, Klingenberg first discovered a pigment in the liver microsomes that binds $\mathrm{CO}$ and demonstrates strong absorbance at $450 \mathrm{~nm}(4,5)$. Four years later, Omura and Sato reported additional properties of this biochemical system and coined the name "cytochrome P450" for "Pigment 450 " $(5,6)$. Early work on P450 proteins was carried out with human tissue samples $(7,8)$. For the several human P450 enzymes, cDNA molecules were cloned in 1980s and the recombinant P450 enzymes were heterologously expressed

Correspondence to: Donghak Kim, Department of Biological Sciences, Konkuk University, 120 Neungdong-ro, Gwangjin-gu, Seoul 05029, Korea

E-mail: donghak@konkuk.ac.kr

This is an Open-Access article distributed under the terms of the Creative Commons Attribution Non-Commercial License (http:// creativecommons.org/licenses/by-nc/3.0) which permits unrestricted non-commercial use, distribution, and reproduction in any medium, provided the original work is properly cited. and purified in mammalian, yeast, and bacterial systems in late 1980 s and early 1990 s (9).

The human genome includes $57 \mathrm{P} 450$ genes (http://drnelson.uthsc.edu/cytochromeP450.html) and among them, about 15 are considered to be primary catalysts of xenobiotic metabolism (10). There are three enzymes in the human P450 1 family including P450 1A1, 1A2, and 1B1. This review will focus on metabolic importance of human P450 1B1 and the role of its polymorphisms in cancer development.

\section{HUMAN CYTOCHROME P450 1B1}

P450 1B1 was originally found in cultures of keratinocytes as a new dioxin-inducible gene (11). In humans, P450 $1 \mathrm{~B} 1$ is expressed primarily in the kidney, spleen, thymus, prostate, lung, intestine, and colon but barely detectable in liver (12,13). Moreover, high P450 1B1 expression has been observed in various hormone-mediated cancers, such as breast, ovarian, endometrial, and prostate cancers (14). P450 1B1 has never been purified from human tissues (12), but Guengerich and colleagues were able to express and characterize the recombinant P450 1B1 enzyme (15).

$\mathrm{P} 450$ 1A1, 1A2, and 1B1 share a common transcriptional regulation through the aryl hydrocarbon (Ah) system, which is comprised of the aryl hydrocarbon receptor $(\mathrm{AhR})$ and AhR nuclear translocator (ARNT) (16). The P450 1B1 gene is transcriptionally activated when a ligand binds to the 


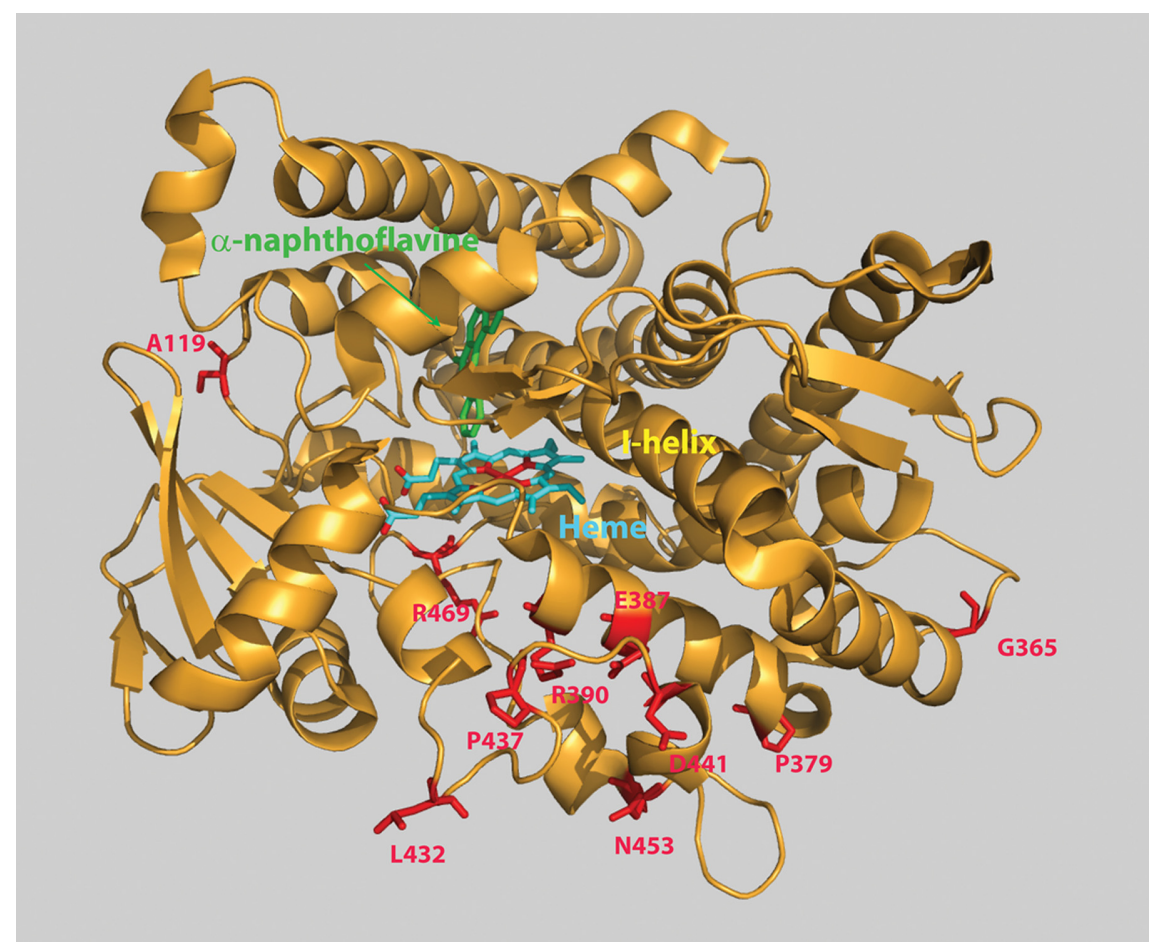

Fig. 1. The X-ray crystal structure of P450 1B1 in the complex with $\alpha$-naphthoflavone (18). Polymorphic residues are indicated in red color.

cytoplasmic AhR complex (17). The ligand bound AhR translocates to the nucleus, where it forms a heterodimer complex with ARNT (17). This tertiary complex of the ligand (e.g., dioxin), AhR and ARNT subsequently binds to enhancer sites of the P450 1B1 gene and opens up the chromatin structure, so that transcription factors can bind to the promoter and cause more rapid transcription (17).

The X-ray crystal structure of P450 1B1 in the complex with $\alpha$-naphthoflavone was determined by Eric Johnson's group (Fig. 1) (18). The narrow substrate binding cavity of P450 1B1 contains a slot-like active site, which is well adapted to bind to its characteristic substrates that possess hydrophobic and planar aromatic ring structures (18). The Phe231 residue of $\mathrm{P} 450$ 1B1 induces a distortion of the Fhelix accommodating for $\pi-\pi$ stacking with $\alpha$-naphthoflavone, a feature also present in the structure of P450 1A2 (Fig. 1) (18).
$O$-deethylation of 7-ethoxyresorufin (EROD) is used as a model reaction catalyzed by $\mathrm{P} 450 \mathrm{1B} 1$. The catalytic activity P450 1B1 is similar to that of P450 1A1 and 1A2 (12). The roles of P450 1B1 in the bioactivation of a very broad spectrum of chemical carcinogens including polycyclic hydrocarbons, heterocyclic amines, aromatic amines, and nitropolycyclic hydrocarbons have been well documented $(12,19)$ (Table 1). An E. coli strain overexpressing P450 and $N$ acetyltransferase has been used to characterize the chemical genotoxicity of P450 enzymes $(20,21)$. A P450 1B1based genotoxicity system has been utilized to characterize potent inhibition of the enzyme by tetramethylstilbene (22).

\section{ASSOCIATIONS OF CANCER AND DISEASES}

P450 1B1 activity has been under a close experimental scrutiny because this enzyme mediates metabolic bioactiva-

Table 1. Chemical carcinogens metabolically activated by human P450 1B1 ${ }^{a}$

\begin{tabular}{lllll}
\hline \hline Polycyclic aromatic carbons & Heterocyclic amines & Aromatic amines & Nitropolycyclic hydrocarbons & Estrogens \\
\hline Benzo $[a]$ pyrene & MeIQ & 2-Aminoanthracene & 1-Nitropyrene & $17 \beta$-Estradiol \\
Dibenzo $[a, l]$ pyrene & MeIQx & 2-Aminofluorene & 2-Nitropyrene & Estrone \\
Benzo $[a]$ anthracene & IQ & 4-Aminobiphyenyl & 6-Nitrochryrene & \\
Dimethylbenz $[a]$ anthtracene & Trp-P1 & O-Aminoazotoluene & 2-Nitrofluoranthene & \\
Benzo $[c]$ phenanthrene-3,4-diol & Trp-P2 & 6-Aminochrysene & 1,8-Dinitropyrene & \\
5-Methylchrysene & PhIP & & 1-Aminopyrene & \\
\hline
\end{tabular}


tion of many chemical carcinogens (Table 1). This functional feature of P450 1B1 helps to understand its role in cancer initiation and progression. As a recognized driver of cancer development, P450 1B1 has been considered a promising cancer biomarker and a potential target for anticancer therapy. In humans, P450 1A1 and 1A2 are believed to be the major enzymes that catalyze the activation of procarcinogenic polycyclic aromatic hydrocarbons (PAHs). However, several studies have established that P450 1B1 also plays a very important role in metabolic activation of PAHs $(13,23,24)$. There have been several reports about the effects of the P450 1B1 gene knockout in vivo. In mice with a knockout of the P450 1B1 gene, lower rates of tumor growth and elevated protection against DNA adduct formation were observed when carcinogenic agents such as 7, 12dimethylbenz $[a]$ anthracene and dibenzo $[a, l]$ pyrene were administered $(23,25,26)$. In addition, P450 1B1 gene-knockout mice displayed attenuated tumor tissue metastasis induced by benzo $[a]$ pyrene (27). These reports strongly imply that the mechanisms of P450 1B1-induced cell proliferation, migration, and invasion may have a considerable preclinical and clinical significance.

P450 1B1 is an efficient catalyst for estrogen hydroxylation. It catalyzes the 4-hydroxylation reaction of $17 \beta$-estradiol $\left(\mathrm{E}_{2}\right)$ that produces the less active metabolite, 4-hydroxyestradiol $(12,17,28,29)$. P450 1A2 and 3A4 can hydroxyl- ate $17 \beta$-estradiol but the major hydroxylated product is 2 hydroxyestradiol (30). 4-Hydroxyestradiol is believed to cause estrogen-dependent tumors (12). It can be converted to chemically more reactive species, quinones and semiquinones, which covalently bind DNA (31). Ortiz de Montellano's group reported that the mutation of Val395 to Leu in human P450 1B1 changed the specificity of the $17 \beta$-estradiol reaction from 4-hydroxylation to 2-hydroxylation (32), which suggested that estradiol carcinogenicity of P450 1B1 depends on that single amino acid residue (32).

Chun and colleagues previously described a selective and potent inhibitor of P450 1B1 and its utility in preventing cancer development (22). Presence of 2,4,3',5'-tetramethoxystilbene (TMS) inhibited EROD activity of P450 1B1 with an $\mathrm{IC}_{50}$ value of $6 \mathrm{nM}$, demonstrating a 500 -fold selectivity over P450 1A2. TMS also strongly and selectively inhibited 4-hydroxylation of 17ß-estradiol by $\mathrm{P} 450 \mathrm{1B} 1$-expressing membranes $\left(\mathrm{IC}_{50} 90 \mathrm{nM}\right)$ or purified $\mathrm{P} 4501 \mathrm{~B} 1\left(\mathrm{IC}_{50}\right.$ $390 \mathrm{nM})(22,33)$. These studies showed that TMS is a selective and potent competitive inhibitor of P450 1B1 and can be considered as a prospective preventive agent for estrogendependent tumors. The molecular mechanism of cancer cell proliferation by P450 1B1 has been revealed recently. The transcription factor Sp1, involved in cell growth and metastasis, was found to be positively regulated by P450 1B1 (unpublished data). It is likely that $\mathrm{P} 4501 \mathrm{~B} 1$ promotes cell

Table 2. Allelic variants of CYP1B1 with polymorphisms located in the coding region

\begin{tabular}{|c|c|c|c|}
\hline Allelic variants & Nucleotide changes & Amino acid changes & References \\
\hline$C Y P 1 B 1 * 2$ & $142 \mathrm{C}>\mathrm{G} ; 255 \mathrm{G}>\mathrm{T}$ & R48G; A119S & $(35,37)$ \\
\hline$C Y P 1 B 1 * 3$ & $4326 \mathrm{C}>\mathrm{G}$ & $\mathrm{L} 432 \mathrm{~V}$ & $(35)$ \\
\hline$C Y P 1 B 1 * 4$ & $4390 \mathrm{~A}>\mathrm{G}$ & N453S & $(35)$ \\
\hline$C Y P 1 B 1 * 5$ & $142 \mathrm{C}>\mathrm{G} ; 4326 \mathrm{C}>\mathrm{G}$ & R48G; L432V & (38) \\
\hline CYP1B1*6 & $142 \mathrm{C}>\mathrm{G} ; 355 \mathrm{G}>\mathrm{T} ; 4326 \mathrm{C}>\mathrm{G}$ & R48G; A119S; L432V & $(38)$ \\
\hline$C Y P 1 B 1 * 7$ & $142 \mathrm{C}>\mathrm{G} ; 355 \mathrm{G}>\mathrm{T} ; 4326 \mathrm{C}>\mathrm{G} ; 4360 \mathrm{C}>\mathrm{G}$ & R48G; A119S; L432V; A443G & $(38)$ \\
\hline$C Y P 1 B 1 * 8$ & $4326 \mathrm{C}>\mathrm{G} ; 4353 \mathrm{G}>\mathrm{C} ; 4379 \mathrm{C}>\mathrm{T}$ & L432V; D441H & Rahman et al., unpublished \\
\hline \multicolumn{4}{|l|}{$C Y P 1 B 1 * 9$} \\
\hline \multicolumn{4}{|l|}{$C Y P 1 B 1 * 10$} \\
\hline$C Y P 1 B 1 * 11$ & $171 \mathrm{G}>\mathrm{C}$ & W57C & $(35)$ \\
\hline$C Y P 1 B 1 * 12$ & $182 \mathrm{G}>\mathrm{A}$ & G61E & $(35)$ \\
\hline$C Y P 1 B 1 * 13$ & 501_502insT & 167Frameshift & $(35)$ \\
\hline$C Y P 1 B 1 * 14$ & $8 \overline{4} 1 \mathrm{G}>\mathrm{T}$ & E281X & (35) \\
\hline$C Y P 1 B 1 * 15$ & 863_864insC & 288Frameshift & (34) \\
\hline$C Y P 1 B 1 * 16$ & Large deletion & Splicing defect & (34) \\
\hline$C Y P 1 B 1 * 17$ & 4096_4108del & 355Frameshift & (34) \\
\hline$C Y P 1 B 1 * 18$ & $4125 \mathrm{G}>\mathrm{T}$ & G365W & (35) \\
\hline$C Y P 1 B 1 * 19$ & $4168 \mathrm{C}>\mathrm{T}$ & P379L & (35) \\
\hline$C Y P 1 B 1 * 20$ & $4191 \mathrm{G}>\mathrm{A}$ & E387K & (35) \\
\hline$C Y P 1 B 1 * 21$ & $4201 \mathrm{G}>\mathrm{A}$ & $\mathrm{R} 390 \mathrm{H}$ & (35) \\
\hline$C Y P 1 B 1 * 22$ & 4232_4241dup & 404Frameshift & (35) \\
\hline$C Y P 1 B 1 * 23$ & $4342 \mathrm{C}>\mathrm{T}$ & P437L & (35) \\
\hline$C Y P 1 B 1 * 24$ & $4377 \mathrm{delG}$ & 449Frameshift & (35) \\
\hline$C Y P 1 B 1 * 25$ & $4437 \mathrm{C}>\mathrm{T}$ & R469W & (35) \\
\hline$C Y P 1 B 1 * 26$ & 4435_4461dup & 477Frameshift & (35) \\
\hline
\end{tabular}

Adopted from "http://www.cypalleles.ki.se/". 
proliferation and metastasis by inducing the epithelial-mesenchymal transition (EMT) and Wnt/ $\beta$-catenin signaling via Sp1 induction (unpublished data). This study suggests that Sp1 acts as a key mediator in the promotion of cancer cell proliferation and metastasis stimulated by P450 1B1.

\section{P450 1B1 POLYMORPHISMS}

Genetic polymorphisms can dramatically alter specific actions of affected proteins. In particular, polymorphisms in genes encoding P450 enzymes have a considerable impact on the fate of xenobiotics, since these subtle DNA changes represent the most frequent cause of variations in oxidative metabolism of drugs or bioactivation of toxicants (5).

To date, at least 25 allelic variants of P450 1B1 have been identified, all of which are located in the coding region (Table 2) (http://www.cypalleles.ki.se/). Stoilov et al. first identified 19 allelic variants of P450 1B1 during the search for genetic variations associated with primary congenital glaucoma (34,35). P450 1B1-deficient mice exhibit abnormalities in their ocular drainage structure and trabecular meshwork that are similar to those reported in human primary congenital glaucoma patients (36). The mechanism of these impairments is still unclear but P450 1B1 is possibly involved in the metabolism of steroids, retinol and retinal, arachidonate, and melatonin (12,36).

Ingelman-Sundberg and colleagues characterized two common P450 1B1 mutations, R48G and A119S (37). The steady-state kinetic analysis showed no differences in $17 \beta-$ estradiol hydroxylation activities in this P450 1B1*2 mutant protein and only a minor increase in the apparent $K_{\mathrm{m}}$ for EROD was observed (37). In another study, three novel allelic variants, P450 1B1*5 (R48G/L432V), *6 (R48G/ A119S/L432V), and *7 (R48G/A119S/L432V/A443G) have been identified in Ethiopian population and functional consequences of these mutations have been analyzed (38). The frequencies of $\mathrm{P} 4501 \mathrm{~B} 1 * 5, * 6$, and $* 7$ were $0.7,6$, and $7 \%$, respectively (38). Recombinant P450 1B1*6 and *7 exhibited altered kinetics with a significantly high apparent $K_{\mathrm{m}}$ and low $k_{\text {cat }}$ values for the hydroxylation of 17 $\beta$-estradiol (38).

Recently, five non-synonymous SNP allelic variants (W57X, 290Frameshift, Y81N, E229K, and R368H) were detected in coloboma/microphthalmia patients (http://www. cypalleles.ki.se/) (39). It is known that P450 1B1 can contribute to retinoic acid synthesis during embryonic development and, at the same time, retinoic acid receptor signaling regulates choroid fissure closure. Functional consequences of expression of these novel P450 1B1 variants observed in that study suggest that $\mathrm{P} 4501 \mathrm{~B} 1$ may regulate proper optic fissure closure by affecting retinoic acid signaling (39).

\section{CONCLUSIONS}

In this review, we considered mechanisms of metabolic activation of chemical carcinogens by P450 1B1. Development of selective P405 1B1 inhibitors with increased therapeutic effectiveness is a promising avenue to control cancer growth and metastasis. Pharmacological roles of P450 1B1 in metabolism of clinical drugs have not been intensively studied.

The risks of metabolic activation of chemical carcinogens in different individuals vary because of polymorphisms in genes encoding metabolic enzymes. P450 1B1 polymorphisms have been implicated as risk factors in various diseases, which may arise from impaired P450 1B1 enzymatic activity. It is therefore extremely important to carefully consider the functional significance of genetic variability of P450 enzymes in the initiation and progression of cancer.

\section{ACKNOWLEDGEMENT}

This paper was supported by Konkuk University in 2013.

\section{REFERENCES}

1. Ortiz de Montellano, P.R. (2005) Cytochrome P450: Structure, Mechanism, and Biochemistry, Plenum Press, New York.

2. Guengerich, F.P. (2001) Common and uncommon cytochrome P450 reactions related to metabolism and chemical toxicity. Chem. Res. Toxicol., 14, 611-650.

3. Porter, T.D. and Coon, M.J. (1991) Cytochrome P-450. Multiplicity of isoforms, substrates, and catalytic and regulatory mechanisms. J. Biol. Chem., 266, 13469-13472.

4. Klingenberg, M. (1958) Pigments of rat liver microsomes. Arch. Biochem. Biophys., 75, 376-386.

5. Lee, I.S. and Kim, D. (2011) Polymorphic metabolism by functional alterations of human cytochrome P450 enzymes. Arch. Pharm. Res., 34, 1799-1816.

6. Omura, T. and Sato, R. (1962) A new cytochrome in liver microsomes. J. Biol. Chem., 237, 1375-1376.

7. Beaune, P., Dansette, P., Flinois, J.P., Columelli, S., Mansuy, D. and Leroux, J.P. (1979) Partial purification of human liver cytochrome P-450. Biochem. Biophys. Res. Commun., 88, 826-832.

8. Wang, P.P., Beaune, P., Kaminsky, L.S., Dannan, G.A., Kadlubar, F.F., Larrey, D. and Guengerich, F.P. (1983) Purification and characterization of six cytochrome P-450 isozymes from human liver microsomes. Biochemistry, 22, 5375-5383.

9. Gonzalez, F.J. (1988) The molecular biology of cytochrome P450s. Pharmacol. Rev., 40, 243-288.

10. Guengerich, F.P. (2004) Cytochrome P450: what have we learned and what are the future issues? Drug Metab. Rev., 36, 159-197.

11. Sutter, T.R., Guzman, K., Dold, K.M. and Greenlee, W.F. (1991) Targets for dioxin: genes for plasminogen activator inhibitor-2 and interleukin-1 beta. Science, 254, 415-418.

12. Guengerich, F.P. (2005) Human cytochrome P450 enzymes in Cytochrome P450: Structure, Mechanism, and Biochemistry (Ortiz de Montellano, P.R. Ed.). Plenum Press, New York, pp. 377-530.

13. Shimada, T., Hayes, C.L., Yamazaki, H., Amin, S., Hecht, 
S.S., Guengerich, F.P. and Sutter, T.R. (1996) Activation of chemically diverse procarcinogens by human cytochrome P450 1B1. Cancer Res., 56, 2979-2984.

14. Chun, Y.J., Oh, Y.K., Kim, B.J., Kim, D., Kim, S.S., Choi, H.K. and Kim, M.Y. (2009) Potent inhibition of human cytochrome P450 1B1 by tetramethoxystilbene. Toxicol. Lett., 189, 84-89.

15. Shimada, T., Gillam, E.M., Sutter, T.R., Strickland, P.T., Guengerich, F.P. and Yamazaki, H. (1997) Oxidation of xenobiotics by recombinant human cytochrome P450 1B1. Drug Metab. Dispos., 25, 617-622.

16. Nebert, D.W., Dalton, T.P., Okey, A.B. and Gonzalez, F.J. (2004) Role of aryl hydrocarbon receptor-mediated induction of the CYP1 enzymes in environmental toxicity and cancer. $J$. Biol. Chem., 279, 23847-23850.

17. Sissung, T.M., Price, D.K., Sparreboom, A. and Figg, W.D. (2006) Pharmacogenetics and regulation of human cytochrome P450 1B1: implications in hormone-mediated tumor metabolism and a novel target for therapeutic intervention. Mol. Cancer Res., 4, 135-150.

18. Wang, A., Savas, U., Stout, C.D. and Johnson, E.F. (2011) Structural characterization of the complex between alphanaphthoflavone and human cytochrome P450 1B1. J. Biol. Chem., 286, 5736-5743.

19. Kim, D. and Guengerich, F.P. (2005) Cytochrome P450 activation of arylamines and heterocyclic amines. Annu. Rev. Pharmacol. Toxicol., 45, 27-49.

20. Parikh, A., Gillam, E.M. and Guengerich, F.P. (1997) Drug metabolism by Escherichia coli expressing human cytochromes P450. Nat. Biotechnol., 15, 784-788.

21. Kim, D. and Guengerich, F.P. (2004) Selection of human cytochrome P450 1A2 mutants with enhanced catalytic activity for heterocyclic amine $N$-hydroxylation. Biochemistry, 43, 981988.

22. Chun, Y.J., Kim, S., Kim, D., Lee, S.K. and Guengerich, F.P. (2001) A new selective and potent inhibitor of human cytochrome P450 1B1 and its application to antimutagenesis. Cancer Res., 61, 8164-8170.

23. Shimada, T. and Fujii-Kuriyama, Y. (2004) Metabolic activation of polycyclic aromatic hydrocarbons to carcinogens by cytochromes P450 1A1 and 1B1. Cancer Sci., 95, 1-6.

24. Rendic, S. and Guengerich, F.P. (2012) Contributions of human enzymes in carcinogen metabolism. Chem. Res. Toxicol., 25, 1316-1383.

25. Buters, J., Quintanilla-Martinez, L., Schober, W., Soballa, V.J., Hintermair, J., Wolff, T., Gonzalez, F.J. and Greim, H. (2003) CYP1B1 determines susceptibility to low doses of 7,12-dimethylbenz[a]anthracene-induced ovarian cancers in mice: correlation of CYP1B1-mediated DNA adducts with carcinogenicity. Carcinogenesis, 24, 327-334.

26. Buters, J.T., Sakai, S., Richter, T., Pineau, T., Alexander, D.L., Savas, U., Doehmer, J., Ward, J.M., Jefcoate, C.R. and Gonzalez, F.J. (1999) Cytochrome P450 CYP1B1 determines susceptibility to 7, 12-dimethylbenz[a]anthracene-induced lymphomas. Proc. Natl. Acad. Sci. U.S.A., 96, 1977-1982.

27. Galvez-Peralta, M., Shi, Z., Chen, J., Miller, M.L. and Nebert,
D.W. (2013) Oral benzo[a]pyrene in CYP1A1/1B1(-/-) double-knockout mice: Microarray analysis during squamous cell carcinoma formation in preputial gland duct. Int. J. Cancer, 132, 2065-2075.

28. Hayes, C.L., Spink, D.C., Spink, B.C., Cao, J.Q., Walker, N.J. and Sutter, T.R. (1996) 17 beta-estradiol hydroxylation catalyzed by human cytochrome P450 1B1. Proc. Natl. Acad. Sci. U.S.A., 93, 9776-9781.

29. Hanna, I.H., Dawling, S., Roodi, N., Guengerich, F.P. and Parl, F.F. (2000) Cytochrome P450 1B1 (CYP1B1) pharmacogenetics: association of polymorphisms with functional differences in estrogen hydroxylation activity. Cancer Res., 60, 3440-3444.

30. Yamazaki, H., Shaw, P.M., Guengerich, F.P. and Shimada, T. (1998) Roles of cytochromes P450 1A2 and 3A4 in the oxidation of estradiol and estrone in human liver microsomes. Chem. Res. Toxicol., 11, 659-665.

31. Bolton, J.L. and Thatcher, G.R. (2008) Potential mechanisms of estrogen quinone carcinogenesis. Chem. Res. Toxicol., 21, 93-101.

32. Nishida, C.R., Everett, S. and Ortiz de Montellano, P.R. (2013) Specificity determinants of CYP1B1 estradiol hydroxylation. Mol. Pharmacol., 84, 451-458.

33. Chun, Y.J., Lee, S.K. and Kim, M.Y. (2005) Modulation of human cytochrome P450 1B1 expression by 2,4,3',5'-tetramethoxystilbene. Drug Metab. Dispos., 33, 1771-1776.

34. Stoilov, I., Akarsu, A.N. and Sarfarazi, M. (1997) Identification of three different truncating mutations in cytochrome $\mathrm{P} 4501 \mathrm{~B} 1$ (CYP1B1) as the principal cause of primary congenital glaucoma (Buphthalmos) in families linked to the GLC3A locus on chromosome 2p21. Hum. Mol. Genet., 6, 641-647.

35. Stoilov, I., Akarsu, A.N., Alozie, I., Child, A., BarsoumHomsy, M., Turacli, M.E., Or, M., Lewis, R.A., Ozdemir, N., Brice, G., Aktan, S.G., Chevrette, L., Coca-Prados, M. and Sarfarazi, M. (1998) Sequence analysis and homology modeling suggest that primary congenital glaucoma on $2 \mathrm{p} 21$ results from mutations disrupting either the hinge region or the conserved core structures of cytochrome P4501B1. Am. J. Hum. Genet., 62, 573-584.

36. Vasiliou, V. and Gonzalez, F.J. (2008) Role of CYP1B1 in glaucoma. Annu. Rev. Pharmacol. Toxicol., 48, 333-358.

37. McLellan, R.A., Oscarson, M., Hidestrand, M., Leidvik, B., Jonsson, E., Otter, C. and Ingelman-Sundberg, M. (2000) Characterization and functional analysis of two common human cytochrome P450 1B1 variants. Arch. Biochem. Biophys., 378, 175-181.

38. Aklillu, E., Oscarson, M., Hidestrand, M., Leidvik, B., Otter, C. and Ingelman-Sundberg, M. (2002) Functional analysis of six different polymorphic CYP1B1 enzyme variants found in an Ethiopian population. Mol. Pharmacol., 61, 586-594.

39. Prokudin, I., Simons, C., Grigg, J.R., Storen, R., Kumar, V., Phua, Z.Y., Smith, J., Flaherty, M., Davila, S. and Jamieson, R.V. (2014) Exome sequencing in developmental eye disease leads to identification of causal variants in GJA8, CRYGC, PAX6 and CYP1B1. Eur. J. Hum. Genet., 22, 907-915. 